Saudi Journal of Medicine

Abbreviated Key Title: Saudi J Med ISSN 2518-3389 (Print) |ISSN 2518-3397 (Online) Scholars Middle East Publishers, Dubai, United Arab Emirates Journal homepage: http://scholarsmepub.com/sjm/

Original Research Article

\title{
Syrian Refugees at Risk of Hepatitis Diseases in Turkey, in Şanliurfa?
}

\author{
Zehra KEKLIK ${ }^{1}$, İbrahim KORUK ${ }^{2}$, Şule ALLAHVERDi ${ }^{3 *}$ \\ ${ }^{1}$ Ministry of Health, Provincial Health Directorate/Şanlıurfa, 63300, Turkey \\ ${ }^{2,3}$ Harran University Faculty of Medicine, Department of Public Health, Sanliurfa, 63300, Turkey
}

DOI: $\underline{\text { 10.36348/sjm.2019.v04i12.002 }}$ | Received: 05.12.2019 | Accepted: 13.12.2019 | Published: 20.12 .2019

*Corresponding author: Şule ALLAHVERDİ

\section{Abstract}

Aim: The aim of this study is to determine the prevalence of hepatitis B/C diseases among Syrian refugees living outside the temporary accommodation centers in Şanlıurfa city center, and individuals' levels of knowledge and risky behaviors related to these diseases. Methods: The research is cross-sectional. It was carried out with 473 Syrian refugees who were living in Şanliurfa city center outside the temporary accommodation centers in April 2015 - 2016. Cluster sampling method was preferred in the selection of the sample. The questionnaire form, which was prepared by the researchers, was applied, and a venous blood sample was collected from the individuals during data collection. HBsAg, Anti-HBs, Anti$\mathrm{HBc}$ total and Anti-HCV levels of the blood samples were examined. Descriptive statistics, Chi-square, and MannWhitney U tests were used in the evaluation of the data. Statistical analyses were performed at $95 \%$ confidence level. p $<0.05$ value was accepted as statistically significant. Results: Of the Syrians, $62.2 \%$ were women and $37.8 \%$ men, with a median age of 34.0. 25.6\% of participants had never attended school, and $82.2 \%$ of them were married. $57.3 \%$ of asylum seekers were Arabian, and $41.9 \%$ were Kurdish. $80.1 \%$ of them didn't know enough Turkish to communicate. Participants' average monthly income was $171 \$$. An average of 8.6 individuals was living in the household, and the individual/room rate was 3.2. 60.3\% of Syrian refugees had not heard of hepatitis B disease, and $69.1 \%$ of them had not heard of hepatitis $\mathrm{C}$ disease. Only $2.3 \%(\mathrm{n}=11)$ of the individuals correctly answered all the questions about the transmission and prevention of hepatitis B/C diseases. 1.7\% of Syrian refugees were HBsAg positive, 23.9\% were Anti$\mathrm{HBc}$ total positive, and $0.4 \%$ of them were Anti-HCV positive. $25.2 \%$ of Syrian refugees were anti-HBS positive, while $7.1 \%$ were immunized with the hepatitis B vaccine. There was no statistically significant difference in the distribution of HBsAg and Anti-HCV antibody status of Syrian refugees according to socio-demographic characteristics and risky behaviors used in this study ( $p>0.05)$. Anti-HBc total antibody positivity was higher in males, in those over 50 years of age, in those who had never attended school and in those who had married at least once $(\mathrm{p}<0.05)$. Anti-HBc total positivity was higher in women, especially in those who had given birth at least once $(\mathrm{p}<0.05)$. Conclusions: The prevalence of hepatitis B/C in Syrian refugees was lower than in Turkey. This suggests that Syrian refugees are at more risk than individuals in our country. Low immunization rates also support this situation. It is believed that the risk of transmission of hepatitis $\mathrm{B} / \mathrm{C}$ diseases can be reduced by giving information about the transmission and prevention ways of hepatitis $\mathrm{B} / \mathrm{C}$ diseases to individuals at marriage age, by screening the group at risk and immunizing them against hepatitis B, increasing the rate of condom use in case of risky sexual intercourse, increasing education level, regular antenatal care of pregnant women and performing HBs Ag screening during this period. Improving socioeconomic status and living conditions of refugees is also crucial in terms of reducing disease transmission, early diagnosis, and treatment.

Keywords: Syrian refugees, hepatitis, infectious diseases.

Copyright @ 2019: This is an open-access article distributed under the terms of the Creative Commons Attribution license which permits unrestricted use, distribution, and reproduction in any medium for non-commercial use (NonCommercial, or CC-BY-NC) provided the original author and source are credited.

\section{INTRODUCTION}

Wars, civil wars, armed struggles against legal authority, ethnic civil wars and their consequences are referred to as complex humanitarian emergencies. Complex human emergencies are characterized by increased health needs of the society, failure to adequately meet vital basic needs and increased mortality. The incidents may lead to large population movement and affect many countries as well as the country in which they take place[1].

It is estimated that there are approximately 1 billion immigrants worldwide, of which 214 million are international immigrants and 740 million are within the home countries[2]. Turkey is both a transit country and a destination country for asylum seekers and refugees, both because of its geographical location and its political, economic and cultural characteristics. 
According to the latest data, there are 35.259 refugees, 166.937 asylum seekers and 2.072.290 Syrian individuals in temporary protection status in Turkey [3].Şanlıurfa, located in the Southeastern Anatolia Region of Turkey, is the most densely populated province with the Syrian refugees and the province with the highest number of camps compared to other provinces. It is estimated that there are 461.280 registered Syrians living in a total of 104.890 camps and 356.390 living out of camps, but this figure is estimated to be much higher with the unregistered individuals[4].

Asylum seekers and refugees often have problems with shelter, nutrition and access to health and social services. In many accommodation centers, sanitation, drinking water, garbage collection and cleaning services are inadequate[5]. Individuals mostly live in tents in a crowded environment [6].In addition to this negative circumstance, there are also significant problems in access to health services due to economic, geographical, administrative and communication problems. The World Health Organization (WHO) states that the majority of refugees only have access to emergency health services and that there are serious problems in accessing curative and preventive health services. Indeed, when the inadequacy of immunization services and poor and overcrowded living conditions combine, the risk of spreading infectious diseases increases [5, 6]. In addition, nearly two million women and children are subjected to sexual assault or abuse each year and may be forced into sexual exploitation or prostitution[7]. These adversities increase the risk of transmission of bloodborne and sexually transmitted diseases among refugees or among the community of the country[8]. Hepatitis $\mathrm{B}$ and $\mathrm{C}$ are particularly important major problems. As a matter of fact, in 2010, the prevalence of HBsAg in Italy was $1-2 \%$ and the prevalence of anti-HCV was between $2 \%$ and $8 \%$ [9], whereas $\mathrm{HBsAg}$ was detected in $8.3 \%$ of the refugees, anti-HBc was detected in $45.6 \%$, anti-HCV was detected in $4.5 \%$, and $1.5 \%$ of the refugees were HIV positive as a result of the screening carried out in Bari, Italy [10]. Again, HBsAg was detected in $9.0 \%$ of the refugees, and anti-HCV was detected in $4.0 \%$, while $1.0 \%$ of the refugees were HIV positive between January 2012-June 2013, in Italy. Of the $801 \mathrm{HBsAg}$ negative individuals, $373(47.0 \%)$ were anti-HBc positive[11]. Considering that approximately 600.000 people die each year due to cirrhosis and liver cancer caused by HBV[12], and that approximately 500.000 individuals [13] die from liver diseases related to $\mathrm{HCV}$, any condition that may increase the frequency and transmission of these diseases should not be ignored.

In the studies involving the whole community, pregnant women, dentists and agricultural workers in Şanliurfa, HBsAg positivity was reported to be between $3.2 \%$ and $4.2 \%$ and Anti-HCV positivity was $1.0 \%$ [1416], while [16] there is no data on Hepatitis B/C diseases in Syrian refugees living in Şanlıurfa[17].
The aim of this study was to determine the prevalence of hepatitis $\mathrm{B} / \mathrm{C}$ diseases among Syrian refugees living outside the temporary accommodation centers in Şanlıurfa city center, and individuals' levels of knowledge and risky behaviors related to these diseases.

\section{MATERIAL AND METHODS}

The research is a cross-sectional study. The data collection phase of the study was carried out between April 2015 - 2016. The universe of the study is the Syrian refugees aged over 18 , who live outside the temporary accommodation centers in 84 neighborhoods in the city center of Şanlıurfa.

Şanliurfa, where the research was conducted, is located in the Southeastern Anatolia Region of Turkey. According to the ranking of the State Planning Organization, and according to the levels of socioeconomic development, which includes education, health and social determinants in the provinces, Şanlıurfa ranks 73rd among 81 provinces [18]. The majority of the population consists of women of reproductive age and children. High levels of fertility (total fertility rate: 4.29; the average number of children of women aged 40-49 years: 4.83), high levels of infant (infant mortality rate: 14.4 per thousand live births), child and maternal mortality, low demand for family planning services and problems with prenatal and postnatal care make maternal and child health services important. $47.7 \%$ of women and $28.2 \%$ of men are illiterate [19].

Of the 2 million Syrian refugees across Turkey, approximately 500 thousand are estimated to live in Şanlıurfa. 109.936 of these individuals live in temporary accommodation centers[20].

Cluster sampling method was preferred in the selection of the sample due to the fact that all of the refugees were not registered and they frequently changed their address. 7 streets were selected for pilot study to calculate the number of clusters. In the pilot study, each cluster diameter was calculated as 11.4 and variance $\left(\mathrm{sp}^{2}\right)$ was calculated as 0.40036 . As the total number of clusters $(\mathrm{N})$ being 6000 , the number of clusters was determined as 40 by taking the estimated tolerance limit (D) as 0.01 and the estimated error limit as (B) 0.0175 , with the cluster diameter and variance obtained from the pilot study. In the cluster selection, streets were selected from the street list obtained from Şanlıurfa Municipality by simple random method. The sample size was 473 people in 40 clusters. The level of participation in the study was $98.0 \%$.

The researchers first applied the questionnaire to the participants and then $10 \mathrm{cc}$ of venous blood samples were collected from the participants.

The questionnaire included sections where socio-demographic characteristics (age, gender, 
educational status, marital status, monthly income status, in-kind/cash assistance receiving status, ethnicity and status of knowledge of Turkish) and the information about the household (duration of residence in Turkey, with whom they live in Turkey, the number of people, number of parents and the number of rooms in the household), the level of knowledge about hepatitis $\mathrm{B}$ and $\mathrm{C}$ (status of having heard of Hepatitis $\mathrm{B} / \mathrm{C}$ diseases, the reuse of used syringes or transmission as a result of accidental needle sticks, a healthy person being given the blood/blood product of a hepatitis $\mathrm{B} / \mathrm{C}$ patient and the disease being transmitted to him/her, transmission by having a permanent tattoo done in unhygienic conditions, disease transmission during tooth extraction in unhygienic conditions, disease transmission during unprotected sexual intercourse and from the mother during delivery, vaccination against hepatitis $\mathrm{B} / \mathrm{C}$ disease, status of increasing the risk of hepatitis $\mathrm{B} / \mathrm{C}$ transmission by having sex with more than one person or having sex with men or women who engage in commercial sex), attitude (men or women's knowledge about what should be done to protect themselves from these diseases in the case of a sexual intercourse) and risky behaviors (status of having surgery, drug use status, the presence of hepatitis $\mathrm{B} / \mathrm{C}$ in himself/herself or his/her family, status of giving birth, and if she gave birth, where and how she gave birth) were inquired.

The total number of correct answers given by the participants to 10 knowledge questions about transmission and prevention of hepatitis $\mathrm{B} / \mathrm{C}$ diseases was taken as the knowledge score.

Venous blood samples were transported daily to the laboratory in the cold chain, centrifuged at 3000 rpm for five minutes and stored at $-30^{\circ}{ }^{\circ} \mathrm{C}$. $\mathrm{HBsAg}$, Anti-HBs, Anti-HBc total and Anti-HCV levels were measured in all blood samples by micro ELISA technique. $\geq 1 \mathrm{IU} / \mathrm{ml}$ for $\mathrm{HBsAg}, \geq 10 \mathrm{mIU} / \mathrm{ml}$ for Anti$\mathrm{HBs}, \leq 1 \mathrm{IU} / \mathrm{ml}$ for Anti-HBc total and $\geq 1 \mathrm{IU} / \mathrm{ml}$ for Anti-HCV, which were the limit values for the laboratory studied, were accepted as positive values.

Dependent variables of the study: Hepatitis B virus infection (HBsAg positivity), Being immune to Hepatitis B virus (Anti-HBs positivity with Anti-HBc total negativity), Exposure to Hepatitis B virus (Anti$\mathrm{HBc}$ total positivity) and Hepatitis $\mathrm{C}$ virus infection (Anti-HCV positivity)

Descriptive statistics, Chi square and MannWhitney U tests were used in the evaluation of the data. Statistical analyses were performed at $95 \%$ confidence level. $\mathrm{p}<0.05$ value was accepted as statistically significant.

\section{FINDINGS}

The mean age of the Syrian refugees was 34.0 years, and $82.2 \%$ were married and $62.2 \%$ were women. $25.6 \%$ of the participants never attended school. $57.3 \%$ of the participants were Arab and $41.9 \%$ were of Kurdish origin. $80.1 \%$ could not speak Turkish. The average monthly income of refugees was $171 \$$. Only $14.0 \%$ of refugees received financial or food aid. Food aid accounted for $84.8 \%$ of these aids. The mean duration of stay of Syrian refugees in Turkey was 12 months. The average number of people living in the household was 7.0 and the person/room ratio of the household was 3.0 (Table 1, Table 5). $50.1 \%$ of the refugees lived with other Syrian families.

Table-1: Distribution of Syrian refugees by socio-demographic characteristics

\begin{tabular}{|l|c|}
\hline & Average (Minimum - Maximum) \\
\hline Age & $34.0(17.0-82.0)$ \\
\hline Monthly income status (\$) & $171(0-1430)$ \\
\hline Monthly cash aid amount (\$) & $86(34-343)$ \\
\hline Duration of stay in Turkey (Months) & $12(0-48)$ \\
\hline Number of people per household & $7(2-32)$ \\
\hline Person/room ratio in the household & $3(0.5-11)$ \\
\hline Number of families per household & $2(1-20)$ \\
\hline
\end{tabular}

$60.3 \%$ of the Syrian refugees had not heard of hepatitis B and $69.1 \%$ of them had not heard of hepatitis C. Only $2.3 \% \quad(n=11)$ of the individuals correctly answered all the questions about the transmission and prevention of hepatitis $\mathrm{B} / \mathrm{C}$ diseases. Of the participants, $27.1 \%$ knew that the disease could be transmitted by re-use of the used syringe or by accidental needle sticks, $27.5 \%$ knew that a healthy person could be infected with hepatitis $\mathrm{B} / \mathrm{C}$ through the transfusion of blood or blood products, $27.1 \%$ knew that they could be infected by having permanent tattoos in unhygienic conditions, $20.9 \%$ knew that they could be infected with unprotected sex, 22.4\% knew that it could be transmitted from mother to baby during delivery and $25.6 \%$ knew that they could be infected during dental extraction in unhygienic conditions. $25.2 \%$ of the Syrian refugees knew that having sex with more than one person and having sex with men or women who engaged in commercial sex increased the risk of transmission of hepatitis B/C. $25.2 \%$ of individuals knew that they could be protected from hepatitis B by getting vaccinated, while $10.4 \%$ knew that they could not be protected from hepatitis $\mathrm{C}$ by vaccination (Table 2). Only $14.8 \%$ of the participants knew that using condoms could protect them from being infected by hepatitis $\mathrm{B} / \mathrm{C}$ during sexual intercourse. The mean total knowledge score of the participants about hepatitis $\mathrm{B} / \mathrm{C}$ diseases is 0.0 . 
Table-2: Distribution of Syrian refugees according to their level of knowledge about hepatitis B/C diseases

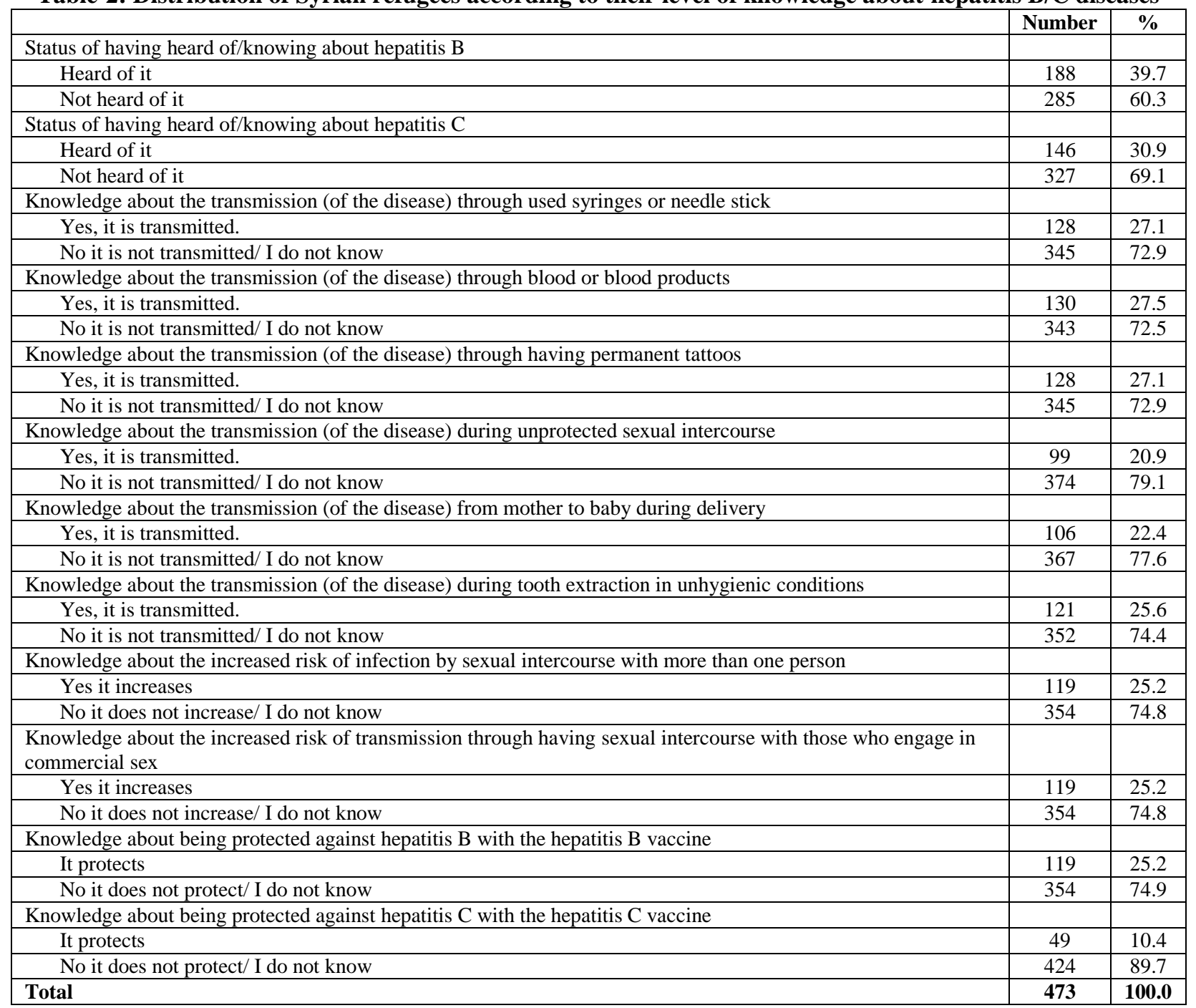

$38.5 \%$ of the Syrian refugees underwent one or more operations for some reasons. Of the women whose $92.8 \%$ gave birth, $83.5 \%$ had normal birth and $39.4 \%$ gave birth at home at least once. Participants did not declare any narcotic drug use (Table 3 ).

Table-3: Distribution of risky behaviors of Syrian refugees towards hepatitis B/C diseases

\begin{tabular}{|c|c|c|}
\hline & Number & $\%$ \\
\hline \multicolumn{3}{|l|}{ Status of having had a surgery } \\
\hline Yes & 182 & 38.5 \\
\hline No & 291 & 61.5 \\
\hline \multicolumn{3}{|l|}{ Status of substance/drug use } \\
\hline Yes & 0 & 0.0 \\
\hline No & 473 & 100.0 \\
\hline \multicolumn{3}{|l|}{ Status of giving birth* } \\
\hline Yes & 261 & 92.8 \\
\hline No & 20 & 7.2 \\
\hline \multicolumn{3}{|l|}{ Types of delivery** } \\
\hline Normal birth & 177 & 67.8 \\
\hline Caesarean section & 43 & 16.4 \\
\hline Normal delivery + Cesarean section & 41 & 15.7 \\
\hline \multicolumn{3}{|l|}{ Place of birth $* *$} \\
\hline Home & 45 & 17.2 \\
\hline Health organizations & 158 & 60.5 \\
\hline Home + Health organizations & 58 & 22.2 \\
\hline
\end{tabular}


$1.7 \%$ of Syrian refugees were HBsAg positive and $23.9 \%$ were Anti-HBc total positive. $25.2 \%$ of Syrian refugees were anti-HBS positive, while $7.1 \%$ were immunized with the hepatitis $B$ vaccine. $0.4 \%$ of the participants were Anti-HCV positive (Table 4).

Table-4: Distribution of Syrian refugees according to HBsAg, Anti-HBs, Anti-HBc total and Anti-HCV status

\begin{tabular}{|l|c|c|c|c|}
\hline & \multicolumn{2}{|c|}{ Positive } & \multicolumn{2}{c|}{ Negative } \\
\hline & Number & $\%$ & Number & $\%$ \\
\hline HBsAg & 8 & 1.7 & 465 & 98.3 \\
\hline Anti-HBs & 119 & 25.2 & 354 & 74.8 \\
\hline Anti-HBc total & 113 & 23.9 & 360 & 76.1 \\
\hline Anti HCV & 2 & 0.4 & 471 & 99.6 \\
\hline Immunized with the vaccine & 34 & 7.1 & 439 & 92.9 \\
\hline
\end{tabular}

There was no statistically significant difference in the distribution of HBsAg and Anti-HCV antibody status of Syrian refugees according to sociodemographic characteristics and risky behaviors used in this study $(\mathrm{p}>0.05)$.
Anti-HBc total antibody positivity was higher in males, in those over 50 years of age, in those who never attended school, in those who were married at least once, and in those who gave birth at least once $(\mathrm{p}<0.05)$ (Table 5, Table 6, Table 7).

Table-5: Distribution of anti-HBc total antibody status of the Syrian refugees according to socio-demographic characteristics

\begin{tabular}{|c|c|c|c|c|c|c|c|}
\hline & \multicolumn{4}{|c|}{ Anti-HBc total } & \multirow[b]{3}{*}{$\%^{* * *}$} & \multirow[b]{3}{*}{$\chi^{2}$} & \multirow[b]{3}{*}{$\mathrm{P}$} \\
\hline & \multicolumn{2}{|c|}{ Positive } & \multicolumn{2}{|c|}{ Negative } & & & \\
\hline & Number & $\%^{*}$ & Number & $\%^{*}$ & & & \\
\hline \multicolumn{8}{|l|}{ Gender } \\
\hline Female & 52 & 17.7 & 242 & 82.3 & 62.2 & & \\
\hline Male & 61 & 34.1 & 118 & 65.9 & 37.8 & 15.5 & $<0.001$ \\
\hline \multicolumn{8}{|l|}{ Educational status } \\
\hline Never attended school & 42 & 34.7 & 79 & 65.3 & 25.6 & & \\
\hline At least attended primary school & 71 & 20.2 & 281 & 79.8 & 74.4 & 9.6 & 0.002 \\
\hline \multicolumn{8}{|l|}{ Marital status } \\
\hline Never married & 2 & 4.4 & 43 & 95.6 & 9.5 & & \\
\hline Married at least once & 111 & 25.9 & 317 & 74.1 & 90.5 & 9.1 & 0.002 \\
\hline \multicolumn{8}{|l|}{ Ethnicity } \\
\hline Arab & 63 & 23.2 & 208 & 76.8 & 57.3 & & \\
\hline Kurd & 49 & 24.7 & 149 & 75.3 & 41.9 & & \\
\hline Turkmen & 1 & 25.0 & 3 & 75.0 & 0.8 & 0.1 & 0.93 \\
\hline \multicolumn{8}{|l|}{ The status of knowledge of Turkish } \\
\hline Speaks Turkish & 18 & 19.1 & 76 & 80.9 & 19.9 & & \\
\hline Cannot speak Turkish & 95 & 25.1 & 284 & 74.9 & 80.1 & 1.1 & 0.28 \\
\hline \multicolumn{8}{|l|}{ Status of receiving aid } \\
\hline Receives aid & 20 & 30.3 & 46 & 69.7 & 14.0 & & \\
\hline Does not receive aid & 93 & 22.9 & 314 & 77.1 & 86.0 & 1.3 & 0.24 \\
\hline \multicolumn{8}{|l|}{$\begin{array}{l}\text { Status of living together with } \\
\text { Turks/Turkish citizens }\end{array}$} \\
\hline Lives together with them & 1 & 20.0 & 4 & 80.0 & 1.0 & & \\
\hline Does not live together with them & 112 & 23.9 & 356 & 76.1 & 99.0 & $* * *$ & 1.00 \\
\hline
\end{tabular}


Table-6: Distribution of total anti-HBc status of the Syrian refugees according to socio-demographic characteristics

\begin{tabular}{|c|c|c|c|c|}
\hline & \multicolumn{2}{|c|}{ Anti-HBc total } & & \\
\hline & Positive & Negative & & \\
\hline & Median(Min-Max) & Median(Min-Max) & MW-U & $\mathbf{P}$ \\
\hline Age & $50.0(19-82)$ & $30.0(17-73)$ & 8547.5 & $<0.001$ \\
\hline Income status & $171.0(0-771)$ & $171.0(0-1430)$ & 19842.0 & 0.69 \\
\hline Duration of residence & $12.0(2-36)$ & $12.0(0-48)$ & 19490.5 & 0.50 \\
\hline Person/room ratio & $3.0(0.7-9.5)$ & $3.0(0-11)$ & 19116.5 & 0.33 \\
\hline Knowledge score & $0.0(0-10)$ & $0.0(0-10)$ & 19621.0 & 0.52 \\
\hline
\end{tabular}

Table-7: Distribution of risky behaviors for Hepatitis B/C according to the Anti-HBc total antibody status of Syrian refugees

\begin{tabular}{|c|c|c|c|c|c|c|}
\hline \multicolumn{7}{|c|}{ Syrian rerugees } \\
\hline & \multicolumn{4}{|c|}{ Anti-HBc total } & \multirow[b]{3}{*}{$\chi^{2}$} & \multirow[b]{3}{*}{$\mathrm{p}$} \\
\hline & \multicolumn{2}{|c|}{ Positive } & \multicolumn{2}{|c|}{ Negative } & & \\
\hline & Number & $\%$ & Number & $\%$ & & \\
\hline \multicolumn{7}{|l|}{ Status of having had a surgery } \\
\hline Yes & 49 & 26.9 & 133 & 73.1 & & \\
\hline $\mathrm{No}$ & 64 & 22.0 & 227 & 78.0 & 1.2 & 0.26 \\
\hline \multicolumn{7}{|l|}{ Status of giving birth* } \\
\hline Yes & 52 & 19.9 & 209 & 80.1 & & \\
\hline No & 0 & 0.0 & 31 & 100.0 & 6.2 & 0.013 \\
\hline \multicolumn{7}{|l|}{ Type of delivery* } \\
\hline Had a normal delivery at least once & 46 & 18.3 & 205 & 81.7 & & \\
\hline Didn't have a normal delivery & 6 & 14.0 & 37 & 86.0 & 0.2 & 0.63 \\
\hline \multicolumn{7}{|l|}{ Place of birth* } \\
\hline Gave birth at home at least once & 27 & 19.9 & 109 & 80.1 & & \\
\hline Did not give birth at home & 25 & 15.8 & 133 & 84.2 & 0.5 & 0.45 \\
\hline
\end{tabular}

*Only women were analyzed.

\section{DISCUSSION}

The majority of the participants were women, young adults and married people. As stated in other studies, the fact that men stay in their countries to fight, that the Syrian population is young in general, and that the young population has high mobility to move away from their environments are effective in these results[21-23]. The educational level of Syrian refugees is quite low. The majority are married, have insufficient financial means and poor housing conditions.

The mean duration of stay of Syrian refugees in Turkey was 12 months. In a study conducted in Jordan, more than half of the individuals who participated in the study were reported to have lived in Jordan for nearly two years [24]. In a study conducted in Gaziantep, the average duration of residence of Syrian refugees in the country is $6.5 \pm 3.0$ months [23]. The ongoing civil war in Syria and the fact that some of these individuals were married to Turkish citizens suggest that some of this community will stay in Turkey for longer. Therefore, Syrian refugees are also required to be included in infectious disease prevention and control programs, including hepatitis B and $\mathrm{C}$ diseases.

The prevalence of hepatitis $\mathrm{B}$ is $1.7 \%$ and the prevalence of hepatitis $\mathrm{C}$ is $0.4 \%$ in Syrian refugees. While these results are very similar to the results of the studies on blood donors in Syria, they are found to be lower than the $4.2 \% \mathrm{HBsAg}$ seropositivity and $1.0 \%$ anti-HCV seropositivity values determined by $[25,26]$ Koruk et al. in their study in the city center of Şanlıurfa in 2008[14]. The rate of Anti-HBs positivity is $9.4 \%$ in blood donors in Syria and $25.2 \%$ in Syrian refugees. The rate of Anti-HBc positivity is $10.3 \%$ in blood donors in Syria and $23.9 \%$ in Syrian refugees [25, 26]. Syrian refugees have low levels of hepatitis B and C. However, when compared with the donor studies in Syria, they can be said to have encountered more Hepatitis B infections. Moreover, the level of those protected by the vaccine is very low. With this aspect, Syrian refugees can be said to be at risk.

Hepatitis $\mathrm{B}$ and $\mathrm{C}$ are diseases that are transmitted both through transfusion of blood and blood products and through sexual intercourse. Conflict and 
war environments and the problems they create make refugees and asylum seekers face with negative situations such as the inability to receive qualified health care, the inability to use safe blood and blood products, sexual abuse and sex trafficking etc. more often [27]. However, the majority of Syrian refugees have not heard of hepatitis $\mathrm{B}$ and/or hepatitis $\mathrm{C}$ and have no knowledge of these diseases. While $27.0 \%$ of the Syrian refugees state that they can be infected with used needles or injectors, this level varies between $59.0 \%$ and $86.0 \%$ in Southeast Asian refugees [28-32]. Approximately $20.0 \%$ of Syrian refugees stated that these infections can be transmitted through unprotected sexual intercourse, whereas in different studies, between $19.0 \%$ and $80.0 \%$ of Southeast Asian refugees stated that they could be sexually transmitted. It should not be overlooked that there may be significant differences between regions when studying such issues. While $34.0 \%$ of Korean refugees and $76.0 \%-91.0 \%$ of Chinese refugees stated that there could be transmission of the disease from mother to baby during birth, $22.0 \%$ of Syrian refugees stated this, at a lower level [3338]. Only $25.0 \%$ of the Syrian refugees stated that they could be protected from hepatitis B by vaccination, whereas $54.0 \%$ to $96.0 \%$ of Southeast Asian refugees knew this information correctly [28-32]. While only $14.8 \%$ of the Syrian refugees knew the right approach to safe sexual intercourse, only $2.3 \%$ of the participants knew all the ways of transmission and prevention of hepatitis $\mathrm{B} / \mathrm{C}$ diseases. In a review of 51 studies, the majority of which were conducted on South East Asian refugees, it was reported that between $19.0 \%$ and $92.0 \%$ of the refugees knew the different ways of transmission of hepatitis B disease. The proportion of those who know that hepatitis $\mathrm{B}$ can be prevented by vaccine varies between $54.0 \%$ and $96.0 \%$. Based on these results, it can be stated that Syrian refugees' levels of knowledge about these diseases are worse than those of Southeast Asian refugees. In the same study, it was stated that the level of knowledge of individuals about hepatitis B disease was related to socioeconomic status, educational status, income level and adequate level of language knowledge. Similarly, the level of knowledge of individuals about hepatitis $\mathrm{C}$ disease was reported to be related to educational status, status of owning a house and a job and the status of receiving the hepatitis $B$ vaccine [39]. As a matter of fact, in a study conducted by Aziz et al. in Iraq, it was reported that $51.1 \%$ of the Syrian refugees did not complete primary school education or did not receive education at all. In a study conducted by [13] Alpay et al. in Gaziantep, it was reported that $59.3 \%$ of the Syrian refugees received education only up to primary school [23].

Only one-fifth of the Syrian refugees in Şanlıurfa can speak Turkish enough to communicate. It is thought that this situation makes it difficult for individuals to access health care services and those who apply for health care services do not receive adequate service due to language problems. Indeed, a study including Syrian refugees in[24] and Ekmekçi's study in Turkey also support this[40]. The per capita monthly income of Syrian refugees is around $\$ 25$, and their housing conditions are not adequate. Demirtaş and Özden, in line with the results of this research, state that the living conditions of the Syrian refugees outside camps in Turkey are bad and that some even live homeless [41]. A significant number of refugees use crowded, poorly sanitized and unhygienic communal living spaces together with other families to reduce costs. As a matter of fact, according to the data of the Turkish Statistical Institute, the person/room ratio in Turkey is 1.1, while the person/room ratio in Syrian refugees is 3.0 [42]. It is known that living in a crowded environment facilitates the horizontal transmission of hepatitis B. On the other hand, the poor economic level also hinders or delays access to health care, resulting in delayed diagnosis and treatment of diseases. All of these adverse conditions are said to facilitate the spread of infectious diseases and even cause epidemics [40, 43-45].

The fact that the majority of refugees are married suggests that they are also sexually active. This increases the risk of encountering diseases that are sexually transmitted. The study by Aziz and Alpay reports that the majority of refugees are married[13].

$38.5 \%$ of the Syrian asylum seekers underwent one or more operations for some reasons, posing a potential risk for hepatitis $\mathrm{B} / \mathrm{C}$ diseases. The majority of women gave birth at least once, and almost half of these are normal births. Approximately $40.0 \%$ gave birth at home at least once. The high fertility rate of the Syrian refugee women reveals the importance of the risk of transmission of the disease to the mother and the baby [46].

Among Syrian refugees, males, married, low educated and those over 50 years of age were exposed to hepatitis B virus more. Similarly, in a study conducted on Afghan refugees, the incidence of hepatitis B and C infection was higher in males and in the 40-49 age group [47]. Low-educated people may have a lower level of knowledge and effort to protect themselves [33, 48]. The risk of encountering the disease increases with the age in those who are sexually active [49]. Multi-partner relationships, especially observed in men, increase the risk [50].

HBV is more common among Syrian refugees who gave birth. However, other studies need to investigate whether this is related to being sexually active or whether the institutions providing maternity services are unable to provide hygienic conditions. In a study conducted in Greece, HBsAg positivity was $13.4 \%$ and anti-HBs positivity was $53.0 \%$ in immigrant Albanian pregnant women. This was thought to be caused by poor socioeconomic status and poor sanitation. This high level of infection and low level of 
protection in pregnant women suggest that both women and their babies are at risk for transmission of hepatitis B infection [51].

When working on sexually transmitted and blood-borne hepatitis B/C diseases, due to insufficient research budget, HIV virus/AIDS, which is as important as other diseases and which is under the same title, could not be studied, and hepatitis $\mathrm{B} / \mathrm{C}$ was given priority because of its higher prevalence. In addition, the fact that the questionnaires were applied with the help of an Arabic-speaking interpreter in the data collection stage because of the fact that Syrian refugees do not speak Turkish constitutes the limitation of our research.

\section{CONCLUSION AND SUGGESTIONS}

The prevalence of hepatitis $\mathrm{B} / \mathrm{C}$ in Syrian refugees was lower than in Turkey. This suggests that Syrian refugees are at more risk than individuals in our country. Low immunization rates also support this situation. It is believed that the risk of transmission of hepatitis $\mathrm{B} / \mathrm{C}$ diseases can be reduced by explaining the transmission and prevention ways of hepatitis $\mathrm{B} / \mathrm{C}$ diseases to individuals at marriage age, by screening the group at risk and immunizing them against hepatitis B, increasing the rate of condom use in case of risky sexual intercourse and increasing education level. Regular antenatal care of pregnant women and performing HBsAg screening during this period is absolutely necessary for both disease prevention and early diagnosis and treatment. Women's giving birth in a hospital environment where hygiene conditions are better and screening in cases where blood transfusion is required will reduce the transmission of disease. Improving socioeconomic status and living conditions of refugees is also important in terms of reducing disease transmission, early diagnosis and treatment.

\section{REFFERENCE}

1. Cohen, A., \& Sayag, G. (2010). The effectiveness of internal auditing: an empirical examination of its determinants in Israeli organisations. Australian Accounting Review, 20(3), 296-307.

2. Kroll, J., Yusuf, A. I., \& Fujiwara, K. (2011). Psychoses, PTSD, and depression in Somali refugees in Minnesota. Social psychiatry and psychiatric epidemiology, 46(6), 481-493.

3. Komiserliği, B. M. M. Y. (2017). Ocak 2017 itibariyle UNHCR Türkiye istatistikleri.

4. Erdoğan, M. M., \& Ünver, C. (2015). Türk iş dünyasının Türkiye'deki Suriyeliler konusundaki görüş, beklenti ve önerileri. Türkiye İşveren Sendikaları Konfederasyonu.

5. Komisyonu, T. İ. H. İ. (2010). Türkiye ${ }^{e e}$ de Bulunan Mülteciler, Sığınmacılar ve Yasa Dışı Göçmenlerin Sorunlarını İnceleme Raporu. Erişim tarihi, 14, 2018.
6. Zencir, M., \& Davas, A. (2014). Suriyeli sığınmacılar ve sağlık hizmetleri raporu. Ankara Türk Tabipleri Birliği Yayınlart.

7. Refugees, S. V. A. (1995). Guidelines on Prevention and Response, UNHCR.

8. Connolly, M. A., Gayer, M., Ryan, M. J., Salama, P., Spiegel, P., \& Heymann, D. L. (2004). Communicable diseases in complex emergencies: impact and challenges. The Lancet, 364(9449), 1974-1983.

9. Veldhuijzen, I. K., \& Hahne, S. J. M. (2010). Hepatitis B and C in the EU neighbourhood: prevalence, burden of disease and screening policies.

10. Tafuri, S., Prato, R., Martinelli, D., Melpignano, L., De Palma, M., Quarto, M., \& Germinario, C. (2010). Prevalence of Hepatitis B, C, HIV and syphilis markers among refugees in Bari, Italy. BMC infectious diseases, 10(1), 213.

11. Coppola, N., Alessio, L., Gualdieri, L., Pisaturo, M., Sagnelli, C., Caprio, N., ... \& Sagnelli, E. (2015). Hepatitis B virus, hepatitis C virus and human immunodeficiency virus infection in undocumented migrants and refugees in southern Italy, January 2012 to June 2013. Eurosurveillance, 20(35).

12. Shepard, C. W., Finelli, L., \& Alter, M. J. (2005). Global epidemiology of hepatitis $\mathrm{C}$ virus infection. The Lancet infectious diseases, 5(9), 558-567.

13. Aziz, I. A., Hutchinson, C. V., \& Maltby, J. (2014). Quality of life of Syrian refugees living in camps in the Kurdistan Region of Iraq. PeerJ, 2, e670.

14. Koruk, S. T., Koruk, I., Gursoy, B., Calisir, C., Yuksel, F., Zeyrek, F. Y., \& Simsek, Z. (2010). Hepatitis B and hepatitis C seroprevalence in the center of Sanliurfa province from Southeastern Anatolia Region and related risk factors. Trakya Universitesi Tip Fakultesi Dergisi, 27(4), 367-372.

15. Tekin-Koruk, S., Koruk, İ., Şahin, M., \& Duygu, F. (2009). Şanlıurfa'da ağı ve diş sağlığg çalışanlarında HBsAg, anti-HBs ve anti-HCV pozitifliği ve risk faktörlerinin değerlendirilmesi. Klimik Derg, 22(2), 55-61.

16. Koruk, İ., Koruk, S. T., Demir, C., Şeyhanoğlu, A. S., \& Kara, B. (2013). Şanlıurfa'da mevsimlik tarım işçilerinin yoğun olarak yaşadıkları bir aile sağlığ1 merkezi bölgesinde gebelerde HbsAg pozitifliği düzeyi ve etkileyen faktörler. Türkiye Halk Să̆liğl Dergisi, 11(3), 149-159.

17. Özpınar, E. (2016). Suriye Krizi Türkiye'de Halk Sağlığını Nasıl Etkiliyor?. 18.07.2016]; Available from: http://www.tepav.org.tr/upload/files/14599342704.Suriye_Krizi_Turkiye__de_Halk_Sagligini_Nas il_Etkiliyor.pdf.

18. Bakanlığı, K. (2013). İllerin ve bölgelerin sosyoekonomik gelişmişlik sıralaması araştırması (SEGE-2011). Bölgesel Gelişme ve Yapısal Uyum Genel Müdürlüğü, Ankara. 
19. Bakanlığı, S. (2013). Hacettepe Üniversitesi Nüfus Etütleri Enstitüsü. Türkiye Nüfus ve Săglık Araştırmalarl, Ankara.

20. Anadolu, A. (2016). En fazla Suriyeli Şanlıurfa ve İstanbul'da. 2016 22.06.2016]; Available from: http://www.ensonhaber.com/en-fazla-suriyelisanliurfa-ve-istanbulda-2016-04-11.html.

21. Inci, R., Ozturk, P., Mulayim, M. K., Ozyurt, K., Alatas, E. T., \& Inci, M. F. (2015). Effect of the Syrian civil war on prevalence of cutaneous leishmaniasis in southeastern Anatolia, Turkey. Medical science monitor: international medical journal of experimental and clinical research, 21, 2100.

22. Pfortmueller, C. A., Schwetlick, M., Mueller, T., Lehmann, B., \& Exadaktylos, A. K. (2016). Adult asylum seekers from the Middle East including Syria in Central Europe: what are their health care problems?. PloS one, 11(2), e0148196.

23. Alpak, G., Unal, A., Bulbul, F., Sagaltici, E., Bez, Y., Altindag, A., ... \& Savas, H. A. (2015). Posttraumatic stress disorder among Syrian refugees in Turkey: a cross-sectional study. International journal of psychiatry in clinical practice, 19(1), 4550.

24. Ay, M., Arcos González, P., \& Castro Delgado, R. (2016). The perceived barriers of access to health care among a group of non-camp Syrian refugees in Jordan. International Journal of Health Services, 46(3), 566-589.

25. Muselmani, W., Habbal, W., \& Monem, F. (2014). Prevalence of" anti-HBc alone" among Syrian blood donors. The Journal of Infection in Developing Countries, 8(08), 1013-1015.

26. Muselmani, W., Habbal, W., \& Monem, F. (2013). Significance of screening antibodies to hepatitis B virus core antigen among Syrian blood donors. Transfusion Medicine, 23(4), 265-268.

27. International Organization for Migration.(2013). International Migration, Health and Human Rights. 2013.

28. Carabez, R. M., Swanner, J. A., Yoo, G. J., \& Ho, M. (2014). Knowledge and fears among Asian Americans chronically infected with hepatitis B. Journal of Cancer Education, 29(3), 522-528.

29. Hwang, J. P., Huang, C. H., \& Yi, J. K. (2008). Knowledge about hepatitis $\mathrm{B}$ and predictors of hepatitis B vaccination among Vietnamese American college students. Journal of American College Health, 56(4), 377-382.

30. Kue, J., \& Thorburn, S. (2013). Hepatitis B knowledge, screening, and vaccination among Hmong Americans. Journal of health care for the poor and underserved, 24(2).

31. Taylor, V. M., Jackson, J. C., Pineda, M., Pham, P., Fischer, M., \& Yasui, Y. (2000). Hepatitis B knowledge among Vietnamese immigrants: implications for prevention of hepatocellular carcinoma. Journal of Cancer Education, 15(1), $51-55$.
32. Wu, C. A., Lin, S. Y., So, S. K., \& Chang, E. T. (2007). Hepatitis B and liver cancer knowledge and preventive practices among Asian Americans in the San Francisco Bay Area, California. Asian Pacific Journal of Cancer Prevention, 8(1), 127.

33. Lee, H. O., Lee, O. J., Kim, S., Hontz, I., \& Warner, A. (2007). Differences in knowledge of hepatitis B among Korean immigrants in two cities in the Rocky Mountain region. Asian Nursing Research, 1(3), 165-175.

34. Coronado, G. D., Taylor, V. M., Tu, S. P., Yasui, Y., Acorda, E., Woodall, E., ... \& Hislop, T. G. (2007). Correlates of hepatitis B testing among Chinese Americans. Journal of community health, 32(6), 379-390.

35. Cotler, S. J., Cotler, S., Xie, H., Luc, B. J., Layden, T. J., \& Wong, S. S. (2012). Characterizing hepatitis B stigma in Chinese immigrants. Journal of Viral Hepatitis, 19(2), 147-152.

36. Li, D., Tang, T., Patterson, M., Ho, M., Heathcote, J., \& Shah, H. (2012). The impact of hepatitis B knowledge and stigma on screening in Canadian Chinese persons. Canadian Journal of Gastroenterology and Hepatology, 26(9), 597-602.

37. Taylor, V. M., Tu, S. P., Woodall, E., Acorda, E., Chen, H., Choe, J., ... \& Hislop, T. G. (2006). Hepatitis B knowledge and practices among Chinese immigrants to the United States. Asian Pacific Journal of Cancer Prevention, 7(2), 313.

38. Vu, L. H., Gu, Z., Walton, J., Peet, A., Dean, J., Dunne, M. P., \& Debattista, J. (2012). Hepatitis B knowledge, testing, and vaccination among Chinese and Vietnamese adults in Australia. Asia Pacific Journal of Public Health, 24(2), 374-384.

39. Owiti, J. A., Greenhalgh, T., Sweeney, L., Foster, G. R., \& Bhui, K. S. (2015). Illness perceptions and explanatory models of viral hepatitis B \& C among immigrants and refugees: a narrative systematic review. BMC public health, 15(1), 151.

40. Ekmekci, P. E. (2017). Syrian refugees, health and migration legislation in Turkey. Journal of immigrant and minority health, 19(6), 1434-1441.

41. Demirtas, U., \& Ozden, A. (2015). Syrian refugees: health services support and hospitality in Turkey. Public health, 129(11), 1549-1550.

42. Türkiye, İ.K.(2011). Nüfus ve Konut Araştırması, 06.06.2016]; Available from http://www.tuik.gov.tr/PreHaberBultenleri.do?id=1 5843.

43. Leblebicioglu, H., \& Ozaras, R. (2015). Syrian refugees and infectious disease challenges. Travel medicine and infectious disease, 13(6), 443.

44. Doocy, S., Lyles, E., Akhu-Zaheya, L., Burton, A., Weiss, W. (2016). Health service utilization and access to medicines among Syrian refugee children in Jordan. Int J Health Plann Manage, 31(1), 2016.

45. Ozaras, R., Leblebicioğlu, H., Sunbul, M., Tabak, F., Balkan, I.I., Yemisen, M, Sencan, I., Ozturk, R.(2016). TheSyrian conflict and infectious diseases. ExpertRev Anti InfectTher, 27:1-9, 2016. 
46. Büyüktiryaki, M., Canpolat, F. E., Dizdar, E. A., Okur, N., \& Şimşek, G. K. (2015). Neonatal outcomes of Syrian refugees delivered in a tertiary hospital in Ankara, Turkey. Conflict and health, 9(1), 38.

47. Khanani, M.R., Ansari, A.S., Khan, S., Somani, M., Kazmi, S.U., Ali, S.H.(2010). Concentrated epidemics of HIV, HCV, and HBV among Afghan refugees. Kasim; Available from: http://www.ncbi.nlm.nih.gov/pubmed/20831883.

48. Chen, H., Tu, S. P., Teh, C. Z., Yip, M. P., Choe, J. H., Hislop, T. G., ... \& Thompson, B. (2006). Lay beliefs about hepatitis among North American Chinese: implications for hepatitis prevention. Journal of community health,31(2), 94-112.

49. Brito, M. O., Hodge, D., Donastorg, Y., Khosla, S., Lerebours, L., \& Pope, Z. (2015). Risk behaviours and prevalence of sexually transmitted infections and HIV in a group of Dominican gay men, other men who have sex with men and transgender women. BMJ open, 5(4), e007747.

50. Remis, R. S., Liu, J., Loutfy, M. R., Tharao, W., Rebbapragada, A., Huibner, S., ... \& Smith, G. (2016). Prevalence of sexually transmitted viral and bacterial infections in HIV-positive and HIVnegative men who have sex with men in Toronto. PloS one, 11(7), e0158090.

51. Malarnitsi-Puchner, A., Papacharitonos, S., Sotos, D., Tzala, L., Psichogiou, M., Hatzakis, A., ... \& Michalas, S. (1996). Prevalence study of different hepatitis markers among pregnant Albanian refugees in Greece. European journal of epidemiology, 12(3), 297-301. 